\title{
Assessment of Drainage Structure by Using ArcGIS Software: The Case of Bale Robe Town, Ethiopia
}

\author{
Gutema Wakjira ${ }^{1}$, Garuma Negasa ${ }^{2}$ \\ ${ }^{1}$ Civil Engineering, Civil and Environmental Engineering, Jimma University, Jimma Ethiopia \\ ${ }^{2}$ Water Resources and Hydraulic Engineering, Engineering and Technology, Wollega University, Nekemte, Ethiopia \\ Email address: \\ gute88wakjira@mail.com (G. Wakjira)
}

\section{To cite this article:}

Gutema Wakjira, Garuma Negasa. Assessment of Drainage Structure by Using ArcGIS Software: The Case of Bale Robe Town, Ethiopia. Journal of Civil, Construction and Environmental Engineering. Vol. 6, No. 5, 2021, pp. 149-160. doi: 10.11648/j.jccee.20210605.14

Received: August 26, 2021; Accepted: October 12, 2021; Published: October 30, 2021

\begin{abstract}
An increase in the frequency of extreme weather events such as heavy storms and floods has been reported in various parts of the world. Ethiopian cities at large, are troubled with storm water leading into floods especially during the rainy season due to inadequate installation of desired infrastructure. In the Robe town since the construction of impermeable surface like roads, sidewalks, buildings and others are highly increasing. They are reducing natural permeable surface that can infiltrate water into the ground. Those impermeable surface are create flooding and more storm water runoff in this town. In this town water flows through road especially during heavy rain are resulted in negative impacts on road pavement performance and on the overall situation of the town's basic infrastructures. The objective of this research was to assess drainage structure in Bale Robe town by using ArcGIS software. The specific objectives of this study were; determining general characteristic of EDS, computing slope and capacity of EDS, identifying highly affected road segment due to improper drainage and recommending appropriate counter measure for identified defects. Majority of the data for the study were obtained from the field survey using surveying equipment and field observation, and some data were collected from concerned sectors. The population contains all existing drainage structures except earthen drainage structure. As a result of the study EDS have different types, and base widths, the capacity of some drainage structure are less than the required capacity while some of them are greater than the required capacity. There were both opened and closed drainage structures with slope of EDS between 0.1 percent and 1.96 percent. The terrain category of the town is flat and rolling. Generally, the EDS in the town has different general characteristics, capacities and different defects. The identified defects were due to different factors; like poor design, poor environmental assessment, and lack of maintenance were the main causes of street flood in the study area. In this town the following measurements should be taken to solve the identified defects, properly cleaning of drainage structure before and after rain, cover open drainage structure, improve the longitudinal gradient of drainage structure and improve the capacity EDS based on the ERA standard and causes of the defects.
\end{abstract}

Keywords: ArcGIS, Asphalt Road, Highway Defects, Drainage Structure, Slope and Capacity

\section{Introduction}

\subsection{Background}

The process of urbanization not only destroys the vegetation cover, but also alters the natural course of water flow. These processes leads to the construction of more roads, sidewalks, buildings and other impermeable surfaces; which is results in reducing natural permeable surface that can infiltrate water into the ground. As a result, these impermeable surfaces will create flooding and more storm water runoff for the town [1].

The developing countries have lost precious infrastructure worth billions of dollars through the deterioration of their highway. If they do not immediately be to do much more to preserve their highway and other infrastructures, they will lose billions more [2]. Ethiopia is a developing country which is actively combating with the challenges on urban infrastructure and service provision. Ethiopian cities at large, are troubled with storm water leading into floods especially during the rainy season due to inadequate installation of desired drainage structure [3]. Though water is very essential 
for all life on earth, it can also cause devastation through erosion and flooding. Due to the development of infrastructures as a result of urbanization, the surface runoff water greatly increased in the town damaging the highway structure. The contributed runoff water thus need to be safely disposed to the rivers/outlet channels so that the functional utility of the road infrastructure maintained and thereby avoid the damages which otherwise occurred to the road and property [4].

Although, there is some drainage structures in the Robe town, during summer season water flows through road especially during heavy rain. This has resulted in negative impacts on road pavement performance and on the overall situation of the town's basic infrastructures like roads and drains.

It is observed that the flooding of roads resulting in the town damaging the road surface. It also accumulates sediments on the road surface which cause anxiety to road users. The occurrence of erosion and street flooding is a common phenomenon which forced vehicles to stop for some moments from their usual activities. So, assessing general characteristics of existing drainage structure, identifying areas of in adequate or improper drainage structure, areas which needs additional drainage structure and then recommending appropriate counter measure for each defect is essential to identify causes of this problem.

Therefore, this study assessed the condition of existing drainage structure in Bale Robe town and ranked the severity of identified defects based on its general characteristics, slopes, environment, types of drainage structures, types of road surface and also types of shoulder with regards to maintenance aspect.

\subsection{Objective of the Study}

The main objective of the study was to assess the drainage structure using ArcGIS Software in Bale Robe Town.

Specific objectives

The specific objectives of this research were:

To determine the general characteristics of the existing drainage structures in the town.

To identify terrain category of the town and compute slope EDS using ArcGIS software

To compute capacity of EDS and locate the highly affected road in the town using GPS equipment.

To recommend the possible counter measure based on severity of identified defects.

\section{Literature Review}

\subsection{General and Definition}

Highway drainage is the process of removing and controlling excess surface and sub-surface water within the right way [5]. As [6] states flooding poses an important threat to roads, and can lead to massive obstruction of traffic and damage to road structures, with possible long-term effects. Other researchers also deal, flooding leads to significant repair costs for road control authorities, access difficulties for emergency services [7], and disruption for road users and the community at large. Because of the time and costs required for rebuilding, sustainable and long-term planning is crucial [8]; therefore, the consideration of flood risk constitutes an important input for decision making in planning this type of infrastructure. Flood risk analysis for road networks allows plans to be carried out in an appropriate manner, allocating resources for prevention, mitigation, and restoration [9].

\subsection{Road Drainage System}

Two different types of drainage systems are commonly used to direct flood from the area surrounding the road and also to evacuate extra water from the highway structure. These are surface and sub-surface systems. The design of road or highway drainage systems varies with factors such as road importance, traffic load, rural or urban area [10].

\subsection{Surface Drainage Systems}

Roadside ditches are an agent of hydro modification and in many cases discharge into natural streams, effectively increasing the drainage density of a landscape [11]. A surface drainage system or ditches (Figure 1) collects and diverts storm water from the highway surface and surrounding areas to avoid street flooding. It also prevents damage to subsurface drains, water supplies (wells) and other sensitive adjacent areas. It decreases the possibility of water infiltration into the highway and retains the pavement bearing capability [10].

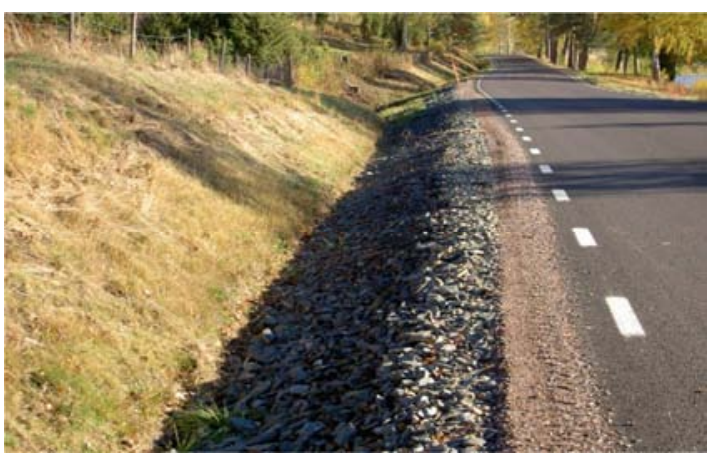

Figure 1. Surface drainage system, photo.

The main purpose of a roadside ditch is to protect the integrity of the highway. Highways are designed to drain rain and snowmelt away from the pavement surface, toward the lower elevation of the roadside ditch. Once the water reaches the ditch, it can flow along the ditch and eventually away from the roadway, protecting the stability of the road subgrade. A ditch may respond to changes such as: increased water flow, blocked channels, removed vegetation and increased sediment load. When its flow is blocked, water seeks a new course. It might carve a new path causing banks to erode or a channel to deepen. As the channel deepens and the banks become near vertical, the upper bank soils might slough to create a shallower slope see Figure 2. 


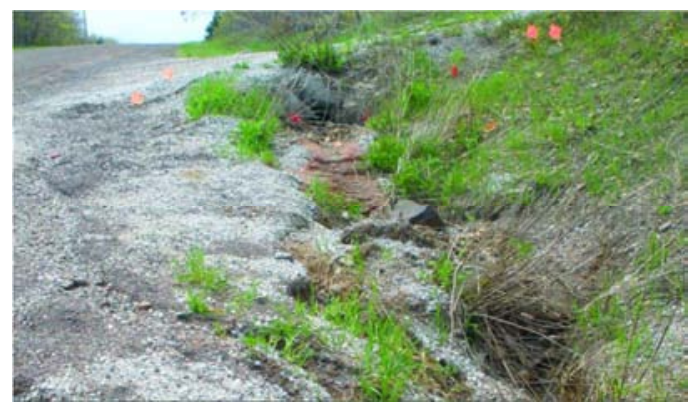

Figure 2. Unstable ditch. Source (Faísca et al., 2012).

\subsection{Types of Road Side Drainages Structure}

Sides drains can be constructed in three common forms: Vshaped, rectangular or as a trapezoid [12].

The V-shape is the standard shape for ditches constructed by a motor grader, But it carries a lower capacity than other cross-section shapes. The rectangular shape requires less space but needs to be lined with rock or concrete to maintain its shape. This shape is often used in urban areas where there is limited space for the drainage. The trapezoid shaped side drain carries a high flow capacity and by carefully selecting the right gradients for its side slopes, will resist erosion [12].

\subsection{Subsurface Drainage Systems (Culverts)}

culvert is a closed conduit for passage of runoff from one open channel to another. One example is a corrugated metal pipe under a roadway. Subsurface drainage systems drain water that has infiltrated through the pavement and the inner slope but also groundwater. Subsurface drainage systems are directly linked to surface drainage systems [10]. According to the SRA handbook, culverts are road constructions with a theoretical span of $2.0 \mathrm{~m}$. Culverts or subsurface drainage system have an open inlet and outlet and conduct water underneath a road. Particular care in both design and maintenance is required to prevent obstruction of water flow by obstacles [13].

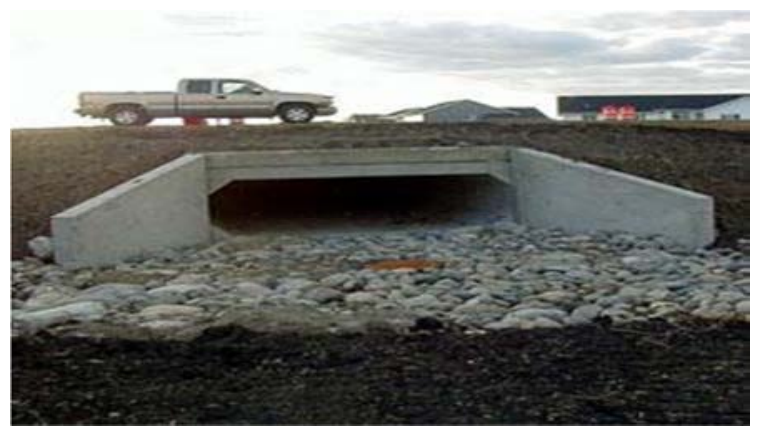

Figure 3. Culverts source [13].

\subsection{Interactions Between Roads and Floods}

Highway structure can be damaged by floods and also can enhance hazardous flood conditions. The flooding of a road induces two levels of consequences: the first consequence is, people may be injured and vehicles disruption of traffic may have severe indirect consequences, like indirect and direct costs. Road closures can have social, economic, and security consequences [14].

Highway structure development in floodplains changes the floodplain hydraulics and affects the related aquatic ecosystems [15]. Figure 4 shows the interactions that can occur between road segments and flows of water or sediment. Roads surface may act as corridors for flows of water on it (A and $\mathrm{B}$ in Figure 4) or in roadside ditches ( $\mathrm{C}$ in figure 4). And roads may be sources of water for stream networks through subsurface drainage structure or culverts ( $D$ in figure 4 ) or gullies ( $\mathrm{E}$ in figure 4$)$. The interaction between highway and rivers may modify the magnitude and direction of water flow and debris, and water flows may transform into debris flows or vice versa [16].

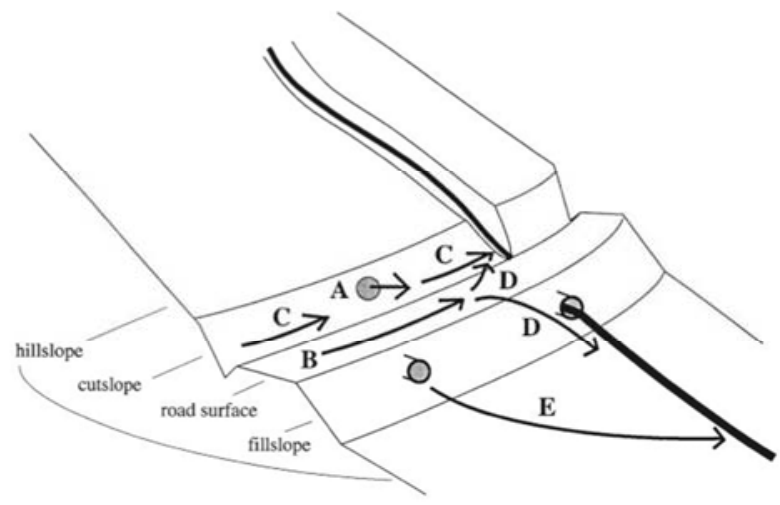

Figure 4. Types of water flow on a road Source: [16].

\subsection{Effects of Flooding in a Road Network}

As many researchers indicate in their publication, poor road side drainage has damage and loss in serviceability of both rigid and flexible types of pavements much greater when structural section contains free water. The quality of drainage is an important parameter which affects the performance of the highway pavement. Poor drainage quality on roads leads to a large amount of costly repairs or replacements long before reaching their design life. Many research works have been carried out on the effect of a poor drainage system on roads as it will reviewed below.

As Buren, $\mathrm{R}$ et al [6] indicates, flooding in a road network can have the following effects. Water that collects on the road because of the failure of flood defenses leads to traffic stagnation or, if the water reaches a certain depth, traffic stoppage. some sections of the road and bridges, creating gullies on peoples' land, blockage of the road, loss of life and property and washing away of the fertility of the land. Poor design, workmanship, and maintenance were the main challenges. He then pushed that drainage facilities should be improved through maintenance; gabions be built for remedying of gullies and construction of water conservation structures e.g. water pans to hold and reduce the speed of water.

Transverse terrains are categorized into four classes as briefly shown in the table 1 [17]. 
Table 1. Terrain category, source [17].

\begin{tabular}{ll}
\hline Terrain & Transverse Terrain Slope \\
\hline Flat & $0 \%-10 \%$ \\
Rolling & $10 \%-25 \%$ \\
Hilly & $25 \%-60 \%$ \\
Mountainous & Above $60 \%$ \\
\hline
\end{tabular}

Terrain can be also classified in to four types. These are a) flat, $<2 \%$, b) rolling, 2-6\%, c) mountain, 6-15\% and d) escarpment, $>15 \%$ [18]. Topographic slopes of land is classified into the following five categories; these are a) flat lands, b) gentle slope lands, c) moderately steep slope lands, d) steep slope lands and e) very steep slope lands [19].

\section{Research Methodology}

\subsection{Description of Study Area}

The study was conducted in Robe town, Bale Zone, Oromia Region at a distance of $430 \mathrm{KM}$ from Addis Ababa. The town was founded in 1930. Robe town is capital of Bale Zone. Its astronomical location is $7^{\circ} 3{ }^{\prime} 30^{\prime \prime}-7^{\circ} 10^{\prime} 45^{\prime \prime}$ North latitude, and $34^{\circ} 57^{\prime} 38^{\prime \prime}-40^{\circ} 2^{\prime} 38^{\prime \prime}$ East longitude. As a result it experiences an annual average temperature of $9^{\circ} \mathrm{C}$ to $25^{\circ} \mathrm{C}$ and annual rainfall totals of between $452.7 \mathrm{~mm}$ and 1129.5 $\mathrm{mm}$, respectively. This District is bordered by Goro District in the east, Dinsho District in west, Agarfa and Gassera in the north and northeast and Goba District in the south. Land areas within the Robe town boundary is $80.24 \mathrm{~km}^{2}$ (Robe town, May, 2018). Figure 5 shows the study area.

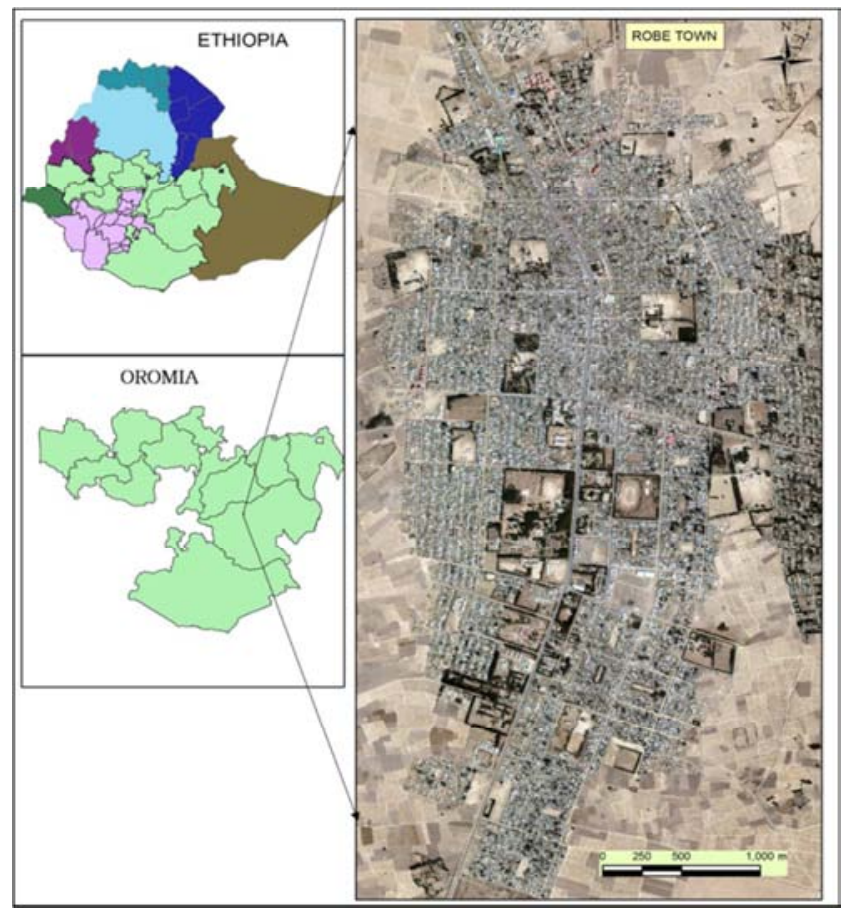

Figure 5. Location map of the study area (source (Robe town, May, 2018)).

\subsection{Study Design}

This research is both qualitative and quantitative in nature. Different kinds of methods and procedures were used to obtain the data regarding dependent and independent variable. Like in other studies review of related literatures were adapted in this study also. The coordinate data collection method and procedure, all other data collection was followed standardized procedure and method; which means secondary data from different organizations and individuals were collected by having legal letter from concerned bodies. In this regard, slope computation, identification of highly affected road and drainage structures, terrain category was classified based on standard method.

\subsection{Study Variables}

\subsubsection{Dependent Variables}

Performance of drainage structure.

\subsubsection{Independent Variables}

1. Types of existing drainage structure.

2. Slope and capacity of existing drainage structure.

3. Types of the surface material.

4. Terrain category of the town.

5. Soil characteristics of the town.

\subsection{Population}

The total number of populations considered in this research, were all drainage structure with in the town except earthen drainage structures. Research work and objective of the research and the total number of populations considered was answering the research question.

\subsection{Sample Size and Sampling Technique}

The sample inspections selected was provided by using purposive sampling. To collect coordinates of each inlet and outlets, and categorize it to different segments same criteria were used. These criteria were types of construction material, types of existing drainage structure based on its shape, types of road surface, types of shoulder, depending on covered or open drainage structure and slope where direction of water flow diverts.

\subsection{Nature and Sources of Data}

As the main objective of this study was to assess the drainage structure of the town, during the study both primary and secondary data were used.

\subsubsection{Primary Data}

Primary data which was used during the study were; coordinates of each upper stream and downstream of existing drainage structures, width, depth, shape of existing drainage structure, covered or open drainage structure and types surface material of existing drainage structures, types of road surface, types of shoulder surfaces, those all data were collected during the field survey and field observation. Data like coordinates (elevation and location), depth, and width, was measured by using surveying equipment like hand held GPS and tape while others was observed during the field observation. 


\subsubsection{Secondary Data}

These data were collected from different concerned bodies. Those data are: image of the site or Orthophoto of the study area, land use of the study area, digital elevation model (DEM) of the study area from EMA, structural plan of the study area, maintenance information, and type of soil from Bale zone irrigation development authority. There were different types of materials used during the study. These were AutoCAD2007 software, ArcGIS 10.3 software, handheld GPS and tape in addition to common Microsoft words.

\subsection{Method of Data Analysis}

The collected data were analyzed according to their types. These all data, both qualitative and quantitative data were analyzed together and then prioritize the drainage structure based on the severity of identified defects. The main purpose of hydrologic analysis is to determine the maximum amount of run-off (peak discharge) that can be accumulated at certain storm drainage outlet (usually a ditch) along a highway/access road alignment section for the design of stormwater drainage system. The Rational Method considers the entire drainage area as a single unit and estimates the peak discharge at the most downstream point of that area. It is, one of the most commonly used simplified models for road storm drainage, is primarily based on the concept that the peak discharge from a watershed will always occur when the rain lasts long enough at its maximum intensity to enable all portions of the basin to contribute to the flow. For this thesis is appropriate because of area for each catchment is less than 50 hectares $(0.5 \mathrm{sqkm})$.

The peak runoff is given by the following expression:

$$
\mathrm{Q}=0.00278 * \mathrm{C} * \mathrm{I} * \mathrm{~A}
$$

Where Q - Discharge at outlet $\left(\mathrm{m}^{3} / \mathrm{s}\right)$

$\mathrm{C}$ - Rainfall-Runoff Coefficient

I -Mximum probable rainfall Intensity $(\mathrm{mm} / \mathrm{hr}$.)

A- Catchment Area (hectares).

The runoff coefficient $(\mathrm{C})$ is the variable of the Rational Method least susceptible to precise determination and requires judgment and understanding on the part of the designer. A typical coefficient represents the integrated effects of many drainage basin parameters. The following discussion considers the effects of soil groups, land use, and average land slope [18]. The rainfall intensity (I) is the average rainfall rate in $\mathrm{mm} / \mathrm{hr}$. for duration equal to the time of concentration for a selected return period. Once a particular return period has been selected for design and a time of concentration calculated for the catchment area, the rainfall intensity can be determined from Rainfall-IntensityDuration curves [18]. A catchment area is determined from topographic maps and field surveys. For large catchment areas it might be necessary to divide the area in to sub catchment areas to account for major land use changes, obtain analysis results at different points within the catchment area [18]. Therefore, for large catchment areas of Bale Robe town, it is necessary to divide the area into sub- catchment areas using AutoCAD 2007 and ArcGIS 103 software based on contour map and structural plan of the study area; to account for common outlet of the town in EDS.

Determining slopes of existing drainage structure is required to identify the segments which accumulates more silts due to flat slope and that exposure to erosion doe to steep slope. To assure flow, ditches should have minimum longitudinal slope of 0.5 percent if unpaved and 0.3 percent if paved Invalid source specified. The minimum grade for unlined drains, including table drains, is $0.5 \%$ and $0.2 \%$ for lined drains however $0.3 \%$ may be regarded as the minimum practical slope for construction (allowing for construction tolerance). This is to ensure that the drain will flow and, if applicable, minimize ponding against formations and pavements. Generally, to achieve the required minimum grades, widening of the table drain is needed over the critical length (or the length where grade is less than that required. However, this solution may not always work, therefore modification or adjustment of the road geometry may need to be made [18].

$$
S=\frac{\mathrm{Z} 1-\mathrm{Z} 2}{\mathrm{~L}} * 100 \%
$$

Where: $\mathrm{S}$ is slope of the drainage segment (\%)

$\mathrm{Z} 1, \mathrm{Z} 2$ elevation of inlet and outlet respectively $(\mathrm{m})$

L length of the drainage segment $(\mathrm{m})$

In this study Z1 and Z2 of each inlet and outlets of all EDS were collected during field survey by using handheld GPS equipment and the value of $\mathrm{L}$, is measured from digitized EDS on ArcGIS 10.3 software.

In this study terrain category of the town was identified from DEM of the town by using ArcGIS software based on ERA manual standard. Because of the following factors:

Design of road drainage in flat terrain is often difficult for several reasons, including: flow velocities in flat areas are usually low so larger structures are needed to convey the flow; flow may be widespread and/or shallow and minor obstructions may divert the flow; these minor obstructions include levees and other floodplain works; and Even the road itself may cause major diversions. In mountainous or steep terrain, the most common factor influencing design is the gradient of the natural ground. Issues for consideration where topography is steep include: control of velocities in roadside drains and culvert outlets; collection and discharge of water from the upward side of the road to the downward side; prevention of erosion at outlets onto steep areas; and the need for small scale drop structures, weirs or drop manholes. During the data analysis DEM of Ethiopia and digitized SP of the town was added to ArcGIS 10.3 software; the digitized SP is used as a boundary to extract DEM of study area from that of Ethiopia. DEM of study area was added to ArcGIS 10.3 software then generate slope of study area from its DEM; classify generated slope as flat, rolling, mountainous and escarpment based on the ERA manual standard.

The general characteristics include type (rectangular, trapezoidal, V-shaped and others), depth, width, and material of existing drainage structure; and some of these properties 
were measured during field survey while others were identified during field observation as well as from Orthophoto of the town.

\section{Result and Discussion}

\subsection{Characteristics of Existing Drainage of Robe Town}

The general characteristics of EDS of the study area were classified on some factors like, based on their types, based on their depth and others. Each percentage given in this subtopic is based on the length of EDS, out of the total constructed length which is $42.5351 \mathrm{KM}$.

\subsubsection{Based on Their Types}

The existing drainage structures were categorized according to their type based on their shape. These types were identified during field observation, and the observed types were rectangular and trapezoidal. As it was shown in Figure 6 only 1.42 percent of existing drainage structure were trapezoidal while 98.58 percent of these drainage structure were rectangular. Both types, rectangular and trapezoidal have their own advantage and dis advantage. Trapezoidal drainage structure require higher space than rectangular drainage structure. Rectangular drainage structure have lower capacity than trapezoidal drainage structure.

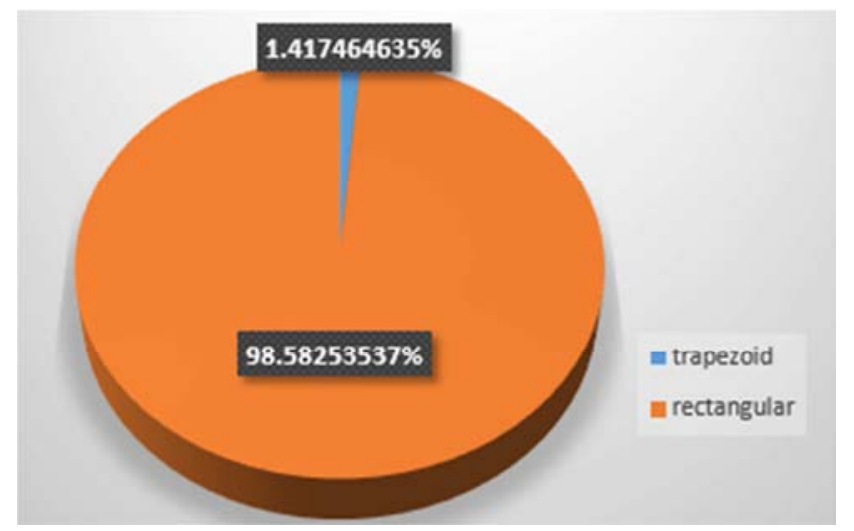

Figure 6. Types of EDS based on their shape.

\subsubsection{Based on the Depth of EDS}

To identify the general characteristics of existing drainage structures the researcher was also measured their depth during field survey. The depth of those EDS ranges between the intervals of $0.75 \mathrm{~m}$ to $0.40 \mathrm{~m}$. As it was shown in Figure 7 , about 23 percent of these drainage structure have a depth of $0.4 \mathrm{~m}, 34$ percent of them have a depth of $0.75 \mathrm{~m}$ while 43 percent of them have a depth of $0.6 \mathrm{~m}$. As [12] states, the exact dimensions of the side drains are dependent on the expected amount of rainwater and the distance to the next exit point where the water can be diverted away from the road. As [18] standard indicates the depth of rectangular drainage structure must be at least $0.75 \mathrm{~m}$; but, in Bale robe town some drainage structure have a depth less than $0.75 \mathrm{~m}$ which do not achieve the ERA manual standard.

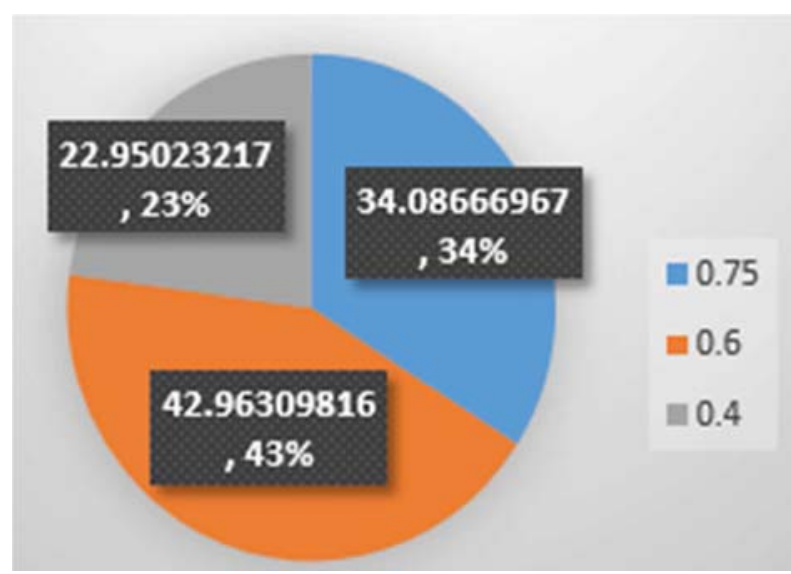

Figure 7. Types of EDS based on its depth.

\subsubsection{Based on Surface Material}

During the computation of discharge value, to know the capacity of drainage structure it is mandatory to know surface material from which they were constructed since different construction material have different rainfall runoff coefficient. So, during the study the researcher was identified the type of those construction material from the report of the town's administration and also through observation. As it was indicated in their report and identified during field observation 33 percent of those drainage structure was constructed from concrete while 67 percent of them were constructed from gravel with mortared at their bottom and masonry at their sides and it was shown also in Figure 8.

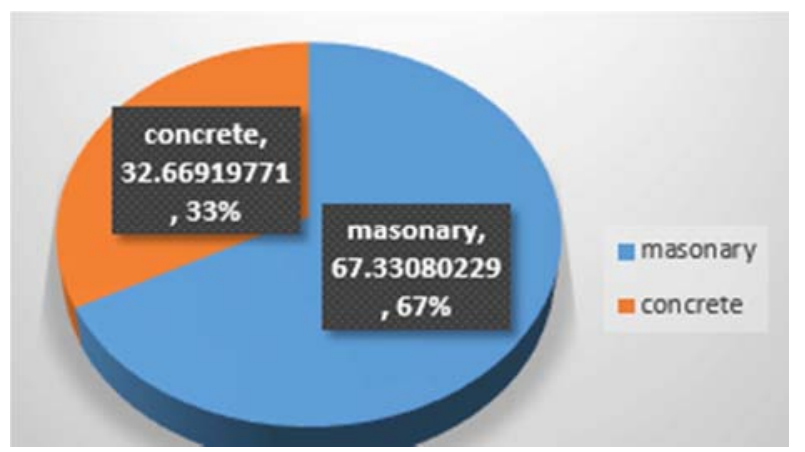

Figure 8. Classes of EDS based on construction materials.

\subsubsection{Based on Either Closed or Open EDS}

During field observation the researcher was categorize the existing drainage structure as closed and open drainage structures. In the Bale Robe Town 69 percent of the EDS are open while 31 percent of EDS are closed as shown in Figure 9. In urban areas especially commercial and residential areas the drains should be covered with concrete slab or small block for easy inspection and cleaning [12]. The deposition of wastes are higher in open drainages structure than in closed drainage structures; because any individual can throw whatever they need in it easily. Those open drainage structures have no good pleasant to the appearance of the town. At some areas it is difficult to cross especially for elders and disabled persons. 


\subsection{Terrain Category of the Town and Slope EDS}

The terrain category of the town was classified based on the standard by using ArcGIS software. These classifications were based on the variation of slope the study area. During this classification DEM of the town was extracted from DEM of Ethiopia, and this DEM was $30 \mathrm{~m} \times 30 \mathrm{~m}$.

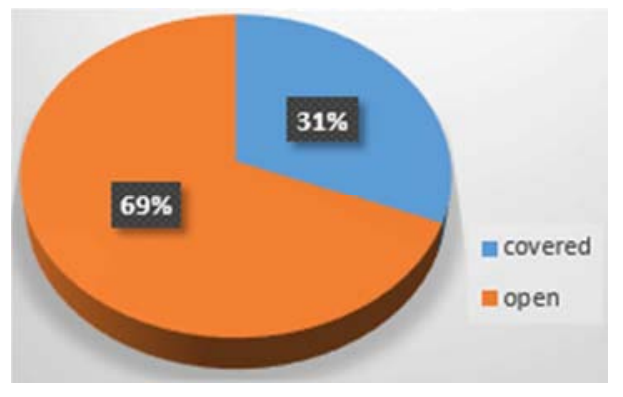

Figure 9. Classes of drainage structure.

During the analysis, the exported digitized structural plan of the town was used as a reference raster. The slope of the town was generated from this DEM and then classified based on standard interval by using ArcGIS software. From this classification, the researcher identified that the terrain category of the town ranges between $0 \%$ to $6 \%$ which is flat and rolling.

To compute slope of drainage structure elevation of both inlet and out lets of all segments of EDS were collected by using hand held GPS during field survey. These collected data were downloaded to computer and saved in Microsoft excel; this saved coordinate data was added to ArcGIS software and labelled during data analysis. After adding this coordinate data to ArcGIS software, the researcher also added orthophoto of the study area to digitize the existing drainage structure by referring added coordinate data and orthophoto of the study area as a background, and then digitized.

After digitizing the existing drainage structure, the slope of all digitized drainage structure segments was calculated in attribute table using ArcGIS software. As [18] the slope greater than 10 percent is too steep slope. Too steep slope drainage can cause erosion and damage drainage structure itself. As study of [12] indicates in flat or slightly undulating terrain, a longitudinal slope to be used is between $2 \%$ and $5 \%$ in the drains. But the value of all computed slopes is less than 10 percent so, there is no drainage structure which expose to erosion due to steep slope. All computed slope has the value of less than 2 percent. So, the existing drainage structures have less than the minimum required value of longitudinal slope. Because of this, the highest and the smallest slope of existing drainage structure were 1.96 percent and 0.1 percent respectively.

\subsection{Capacity of EDS and Location of Highly Affected Road}

\subsubsection{Capacity of EDS}

In Ethiopia, most of the time when they construct drainage structure, they do not consider the required capacity of the drainage structure, especially when it will be constructed at local or town administration level. In this research the researcher checked the capacity of all existing drainage structures of the study area except earthen drainage structure. To check this capacity the depth and width of each segment were measured during field survey, distance of overland flow and catchment area were measured based on contour map of the town using ArcGIS software. The land use of the town was extracted from Bale Zone's classified land use; and to extract it from this zone's land cover the reference raster data was exported from structural plan of the town. The structural plan of the town was drawn using AutoCAD software, by the town administration. So during data analysis to use this structural plan as a reference or boundary, add it to ArcGIS and then export this structural plan to digitize. Add LULC of the town and digitized structural plan of the town respectively, but, both of them have to the same coordinate system, then extract LULC of Robe town from that of Bale zone by using digitized structural plan of the town as a reference raster or boundary.

To determine discharge value of the area determining the overland distance and overland slope is required. The overland slope is calculated from contour map. The overland distance was measured based on the contour map and flow direction of the study area by using ArcGIS 10.3 software. The flow direction of the area was generated from the generated slope of the study area by using ArcGIS software.

Digitized EDS, contour map of the study area and flow direction were overlapped together and the catchment area of each EDS segment were computed.

Samples of this calculated capacity were shown in the following calculation.

Sample 1

Site survey data

Depth $=0.4 \mathrm{~m}$

Slope of ditch $=0.63 \%$

Base $=0.3 \mathrm{~m}$

Length of ditch $=330.81 \mathrm{~m}$

Over land distance $=127.83 \mathrm{~m}$

Residential $=4.8587$ hec.$=93.879 \%$ of $A_{\text {total }}$

Shape $=$ rectangle undeveloped land $=0.3168$

hec. $=6.121 \%$ of $\mathrm{A}_{\text {total }}$

Over land slope $=0.5 \%$ functional class of the road is main access road, so its design storm frequency is 5year [18].

Total area $=5.1755$ hec.

Hydrological group of the study area is Group D from [18] As the report of the Bale Zone Irrigation Development Authority (2015) indicates the soil type of the town is clay loam. Clay loam soil type is categorized under group D according ERA manual [18].

Table 2. Runoff coefficient for sample 1 .

\begin{tabular}{lllll}
\hline S. & Land use & $\begin{array}{l}\text { Land area } \\
\text { No. }\end{array}$ & $\begin{array}{l}\text { Runoff } \\
\text { coefficient (C) }\end{array}$ & AC \\
\hline 1 & Residential & 0.93879 & 0.375 & 0.3520 \\
2 & $\begin{array}{l}\text { Undeveloped (soil } \\
\text { group D) }\end{array}$ & 0.06121 & 0.225 & 0.0138 \\
\multicolumn{2}{l}{ Total weighted runoff coefficient } & & 0.3658 \\
\hline
\end{tabular}


Overland flow time $\left(\mathrm{T}_{1}\right)=83 \mathrm{~min}$. Source ERA 2002, by using distance of $127.83 \mathrm{~m}$ and over land slope of $0.5 \%$.

To determine time of flow within the ditch, first compute velocity of the water within the ditch; by using the formulae:

$$
V=\frac{1}{n} * \mathrm{R}^{2 / 3} * \mathrm{~S}^{1 / 2} \text { but } \mathrm{R}=\mathrm{A} / \mathrm{p} \text { and } \mathrm{P}=(2 \mathrm{~d}-\mathrm{x})+\mathrm{w}
$$

Where:

V: flow velocity within the ditch, $\mathrm{m} / \mathrm{s}$

$\mathrm{P}$ : wetted perimeter of ditch, $\mathrm{m}$

$\mathrm{R}$ : hydraulic radius, $\mathrm{m}$

$\mathrm{d}$ : depth of ditch, $\mathrm{m}$

s: slope of the ditch, \%

w: base width of ditch

$X$ depth of structure above wetted depth (ditch free board)

$\mathrm{n}$ manning's roughness coefficient

$\mathrm{A}=0.4 \mathrm{~m} * 0.3 \mathrm{~m}=0.12 \mathrm{~m}^{2}$

$\mathrm{P}=(2(0.4-.05)+0.3=1 \mathrm{~m}, \mathrm{R}=\mathrm{A} / \mathrm{p}=0.12 \mathrm{~m}$

The ditch was gravel bottom with concrete therefore $\mathrm{n}=0.023$ (ERA 2002)

$\mathrm{V}=1 / 0.023 * 0.12^{2 / 3} * 0.63^{1 / 2}$

$\mathrm{V}=0.1656 \mathrm{~m} / \mathrm{s}$

$\mathrm{V}=$ distance $/$ time,

$\mathrm{T}=\mathrm{L} / \mathrm{V}=(330.81 \mathrm{~m} / 0.1656 \mathrm{~m} / \mathrm{s}) *(1 \mathrm{~min} / 60 \mathrm{~s}) \quad$ since the conversion factor of minute and second is 60

$\mathrm{T}=33 \mathrm{~min}$.

Time of concentration $(\mathrm{Tc})=\mathrm{T} 1+\mathrm{T} 2=83+33=116 \mathrm{~min}$

Intensity (I) was taken from (ERA2002) using TC above and design storm frequency year $=5 \mathrm{yr}$, since the functional class of road is main access road.

$\mathrm{I}=45 \mathrm{~mm} / \mathrm{hr}$.

$$
\begin{aligned}
\mathrm{Q} & =0.00278 * \mathrm{c} * \mathrm{I} * \mathrm{~A} \\
& =0.00278 * 0.3658 * 45 * 5.1755 \\
& =0.2368 \mathrm{~m}^{3} / \mathrm{s}
\end{aligned}
$$

To check the capacity of existing drainage structure; use the formulae,

$$
\mathrm{Q}=\mathrm{AV}
$$

By taking $\mathrm{w}=0.3$, and check the value of depth, $\mathrm{d}$ by trial and error.

$\mathrm{A}=0.3 \mathrm{~d}, \mathrm{R}=\mathrm{A} / \mathrm{p}$, and $\mathrm{p}=2(\mathrm{~d}-0.05)+0.3=2 \mathrm{~d}+0.2$

$$
\mathrm{Q}=(1 / \mathrm{n}) *(\mathrm{w} * \mathrm{~d}) *\left((\mathrm{wd} /(2(\mathrm{~d}-0.05)+\mathrm{w}))^{2 / 3} *(\mathrm{~S})^{1 / 2}\right.
$$

By substituting the value of $\mathrm{Q}, \mathrm{S}$, and $\mathrm{w}$, in equation 5 $0.2368=(1 / 0.023) *(0.3 * \mathrm{~d}) *\left((0.3 \mathrm{~d} /(2 \mathrm{~d}+0.3))^{2 / 3} *(0.63)^{1 / 2}\right.$

$0.0069=0.09 \mathrm{~d}^{2} /(2 \mathrm{~d}+0.2)$ by inserting the value of depth of existing drainage structure. $\mathrm{d}=0.4$

$0.0069<0.0144$ from this computation the capacity of existing drainage structure is greater than the peak discharge (Q) value, therefore it is $\mathrm{OK}$.

Sample 2

Site survey data

Depth $=0.6 \mathrm{~m}$, slope of ditch $=0.63481 \%$, Base $=0.4 \mathrm{~m}$, length of ditch $=330.81 \mathrm{~m}$, Over land distance $=7$, Residential $=2.3107$ hec. $=84.8026 \%$ of $\mathrm{A}_{\text {total }} \quad$ Shape $=$ rectangle walk and derive $=0.4141$ hec. $=15.1974 \%$ of $\mathrm{A}_{\text {total }}$.

Over land slope $=0.68 \%$ functional class of the road is main access road, so its design storm frequency is 5year (ERA 2002), Total area $=2.7248$ hec.

Hydrological group of the study area is Group D from (ERA 2002).

Table 3. Runoff coefficient for sample 2.

\begin{tabular}{lllll}
\hline S. No. & Land use & $\begin{array}{l}\text { Land area } \\
\text { (A) }\end{array}$ & $\begin{array}{l}\text { Runoff } \\
\text { coefficient (C) }\end{array}$ & AC \\
\hline 1 & Residential & 0.848025543 & 0.375 & 0.31801 \\
2 & Walk and derive & 0.151974457 & 0.8 & 0.12158 \\
\multicolumn{2}{l}{ Total weighted runoff coefficient } & & 0.43959 \\
\hline
\end{tabular}

Overland flow time $\left(\mathrm{T}_{1}\right)=56 \mathrm{~min}$. Source ERA 2002, by using distance of $76 \mathrm{~m}$ and over land slope of $0.68 \%$.

To determine time of flow within the ditch, first compute velocity of the water within the ditch; by using the equation (3)

$$
\begin{aligned}
& \mathrm{A}=0.6 \mathrm{~m} * 0.4 \mathrm{~m}=0.24 \mathrm{~m}^{2} \\
& \mathrm{P}=(2(0.0 .6-.2)+0.3=1.2 \mathrm{~m} \\
& \mathrm{R}=\mathrm{A} / \mathrm{p}=0.2 \mathrm{~m}
\end{aligned}
$$

The ditch was gravel bottom with concrete therefore $\mathrm{n}=0.023($ ERA 2002)

$$
\mathrm{V}=1 / 0.023^{*} 0.2^{2 / 3} * 0.63481^{1 / 2}
$$$$
\mathrm{V}=0.46187 \mathrm{~m} / \mathrm{s}
$$

$\mathrm{V}=$ distance $/$ time

$\mathrm{T}=\mathrm{L} / \mathrm{V}=(330.81 \mathrm{~m} / 0.1656 \mathrm{~m} / \mathrm{s})$

$*(1 \mathrm{~min} / 60 \mathrm{~s})$ since the conversion factor of minute and second is $60 \mathrm{~T} 2=11.9373 \mathrm{~min}$. Time of concentration $(\mathrm{Tc})=\mathrm{T} 1+\mathrm{T} 2 .=56 \mathrm{~min}+11.9373 \mathrm{~min}=68.4373 \mathrm{~min}$. Intensity (I) was taken from (ERA2002) using TC above and design storm frequency year $=5 \mathrm{yr}$., since the functional class of road is main access road.

$\mathrm{I}=41 \mathrm{~mm} / \mathrm{hr}$.

$\mathrm{Q}=0.00278 * \mathrm{c} * \mathrm{I} * \mathrm{~A}$

$=0.00278 * 0.43959 * 41 * 2.7248$

$=0.13652 \mathrm{~m}^{3} / \mathrm{s}$

Using equation (6) the capacity of existing drainage structure is $\mathrm{Q}=(1 / \mathrm{n}) *(\mathrm{w} * \mathrm{~d}) *\left((\mathrm{wd} /(2(\mathrm{~d}-0.2)+\mathrm{w}))^{2 / 3} *(\mathrm{~S})^{1 / 2}\right.$

By substituting the value of $\mathrm{Q}, \mathrm{S}$, and $\mathrm{w}$, in equation 6

$0.13652=(1 / 0.023) *(0.4 * d) *((0.4 \mathrm{~d} /$

$(2 \mathrm{~d}+0.1))^{2 / 3} *(0.63481)^{1 / 2}$

$0.0039411=0.16 \mathrm{~d}^{2} /(2 \mathrm{~d}+0.1)^{2 / 3}$ by inserting the value of depth of existing drainage structure. $d=0.4$

$0.0039411>0.0007$ from this computation the capacity of existing drainage structure is less than the peak discharge (Q) value. Therefore, it is inadequate. From these computations it was identified that the capacity of some EDS was less than the required capacity while others were greater than the required capacity

\subsubsection{Location of Highly Affected Road in the Town}

To locate highly affected road segment due to improper drainage, identification and prioritization of defects of EDS was done. Based on the defects of these drainage structure, the drainage structure which has smaller slope value, open drainage structure and the surface of the road is unpaved they 
were highly affected; while the drainage structure which has greater slope value, closed drainage structure, and paved road surface were considered safe. Evaluating the slope of existing drainage structure was required since deposition of sediments or accumulation of silt was observed during field observation. During field observation the researcher also observed some parts of drainage structure were used as garbage area especially at the location of open drainage structures.

Throughout the town, improper connection between the road surface and drainage structure was common. The drain structure, which drains water from road surface to road side drainage structure filters the water to road side drainage and retain the solid materials. The solid material that was retained on the drain was clogging these drains and causing the street flood.

Based on these factor prioritization and location of affected road segments were made during the study by using ArcGIS software. To identify segment of road which is highly affected due to either inadequate or improper existing drainage structure, it is necessary to identify the highway defect which can be caused by poor drainage. As [20] stated in his research, edge cracking can be caused by poor or inadequate drainage and difference in elevation between pavement and shoulder. Also, as [21] stated in his studies, joint cracking can be caused by deformational loads due to thermal expansion and contraction or alternate wetting and drying and it also can be caused by intrusion of water as a result of inadequate drainage. The Asset Inventory result also revealed that, there was a total of $3.41 \mathrm{Km}$ length of pedestrian walkway in the Robe town. During field observation the researcher identified types of surface material of walkways. The surface of $2.38 \mathrm{~km}(69.8 \%)$ is gravel, 0.85 $\mathrm{km}$ or $25 \%$ of this walkway is cobble and $0.053 \mathrm{~km}$ or $5.2 \%$ is clay tile.

So, the researcher was identified road segments which have the above defects and ranges its severity from highly affected to save. As stated earlier in this thesis, roads of the town have different surfacing materials. Roads of earthen, compacted earthen, gravel and cobble stone surface material have no shoulders, and so the investigation of the above defects did not do for them this investigation was done only for paved roads which have shoulder.

The researcher divides paved roads in to seven segment sections based on their direction; and then subdivides those segments in to a length of 100 meters. A first road segment is a road from Muluwangel church to general Wako Gutu roundabout, a second segment is from general Wako Gutu roundabout to Secomando hotel, a third segment is from Secomando hotel to general market area, a fourth segment is from bus station to general market area, a fifth segment is from Gebrechristos church to Auraris, a sixth segment is from Auraris to Hamza mosque, and the seventh segment is from Gobba outlet to Shaya outlet. But from the seventh segment, starting from Robe TVET to Yetebabarut, same defects which is rare joint cracks between pavement and side drainage structure was observed. So the consideration was given to the outlets of this segment, which is from Gobba outlet to Robe TVET and from yetebabrut to Shaya outlet which has no built drainage structure. Total length of the seventh segment is $6411 \mathrm{~m}$; from this segment, Gobba outlet to TVET is $1415 \mathrm{~m}$, TVET to yetebaberut is $4078 \mathrm{~m}$ and yetebabarut to Shaya outlet is $918 \mathrm{~m}$. So, in the Appendix 5 the first 14 subdivisions in front of segment seven indicates Gobba outlets to Robe TVET while the last 9 subdivisions indicate from yetebabarut to Shaya outlets.

\subsection{Observed Defects of Drainage Structure}

\subsubsection{Plants Growing in Existing Drainage Structures}

Plants are highly growing in the existing drainage structure and these plants are the main causes of clog to those drainage structures and are causing street flooding in Bale Robe town. The plants within the drainage structure were not removed earl; even the height of some plants is greater than the depth of the drainage structure that they grow in it. As plants growth with in drainage structure, these plants occupy the capacity of this drainage structure and can causes street flooding.

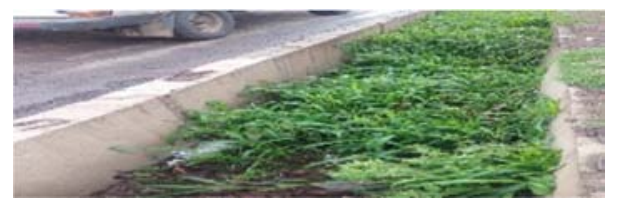

Figure 10. Plants grown in drainage structure, photo.

\subsubsection{Construction Materials and Dry Wastes Deposited in Drainage Structures}

In Bale Robe Town, as stated above in Figure 9 of this document, about 69 percent of the existing drainage structure is open drainage structure. There is also no garbage or gunge nears the roads. So, the road users and the surrounding society are using this existing drainage structure as garbage. Therefore, the existing open drainage structures were blocked by dry waste including very small waste like plastic to some large crap like dead animals. Construction materials were also deposited in drainage structures.

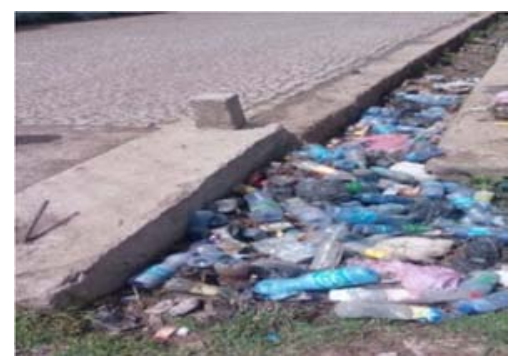

Figure 11. Deposited wastes in the drainage structure.

\subsubsection{Improper Release of Water from Existing Drainage Structure}

Water from existing drainage structure of the town are released to some structure and farm lands of the surrounding society at some parts of the town. At some areas, it was released to collector roads and it is damaging these roads. At other parts of the town, it releases water to farmland and 
damaging these farms by erosion and formation of gullies. So, the surrounding society block theses drainage structures to preserve their farms from the expected damage. Those blocked drainage structures are damaging drainage structure itself, hazard to surrounding society, affecting appearance of the town and damaging the other structures.

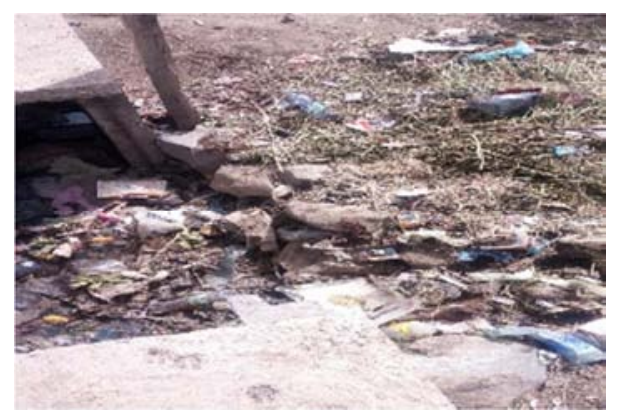

Figure 12. Water released to some facilities.

\subsubsection{Improper Connection between Carriage Ways and Drainage Structure}

The carriage ways of the highway and side drainage structures were not properly connected. The drains, the structure which remove water from carriage way to side drainage, were clogged by sediments and other wastes. So, water from carriage way do not enter in to the drains instead it flows on carriage ways of the highway.

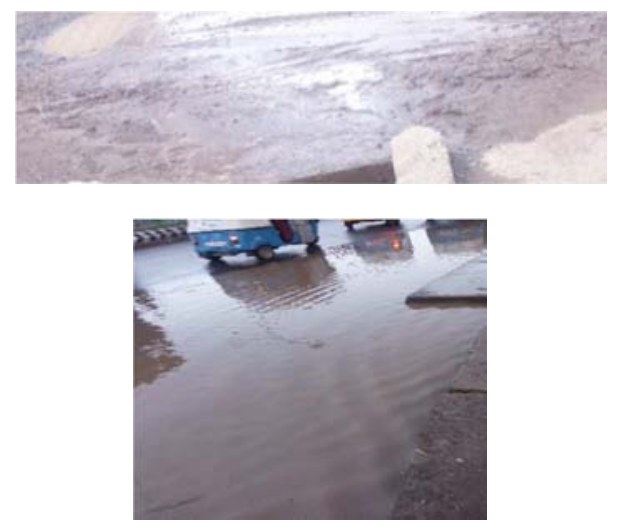

Figure 13. Improper connection of carriage way and side drainage structure.

\subsubsection{Sediment Deposition in the Drainage Structure}

During field observation deposition of sediment in the existing drainage structure was also identified as another defect. The study of [12] was indicating, if the longitudinal gradients less than 2 percent silting occur easily. While with gradients steeper than $5 \%$ the ditches will easily erode. As the researcher indicate in the computation of slope of existing drainage structure all drainage structure's longitudinal slope is less than 2 percent, it is one of the factors that causing siltation in this town.

Since some wastes and construction materials deposited in drainage structure, outlets of some drainage structure were closed and plants are highly growing in the drainage structure water cannot flow as fast as proposed speed. As this speed decreases the sedimentation increases, and fill up some parts of drainage structure and causes street flood.

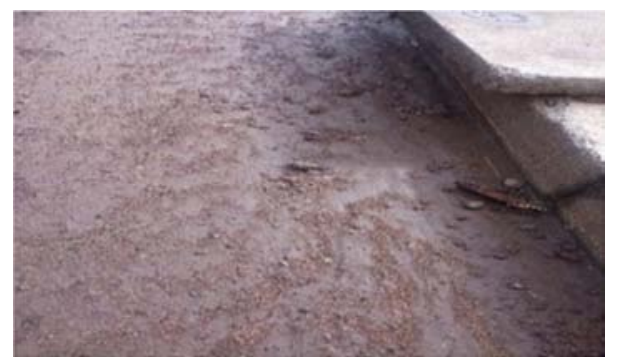

Figure 13. Sedimentation of road surface and drainage structure

\section{Conclusions}

This study was carried out to describe the general characteristics of existing drainage structure, categorize terrain category of the area, and identify defects of existing drainage structure, major causes of street floods in the town and to recommend the appropriate counter measures for the identified defects. To achieve these goals the researcher was made detail field observation and field survey and also collects some data like DEM, LULC, structural plan of the town and orthophoto of the town from concerned bodies. The conclusions of the research were summarized as follows:

This study shows that the general characteristics of existing drainage structure were identified during field observation. These general characteristic were based on types of existing drainage structure, $1.42 \%$ is trapezoidal while $98.58 \%$ is rectangular, based on its depth $23 \%$ of drainage structure's depth is $0.4 \mathrm{~m}, 34 \%$ is $0.75 \mathrm{~m}$ and $43 \%$ is $0.6 \mathrm{~m}$. Based on upper part of existing drainage structure, only $31 \%$ of existing drainage structure was covered while $69 \%$ of the existing drainage structures were open. There are different functional classes of roads in the town. Those roads have different surfacing material like: earthen roads, compacted earthen, gravel, cobblestone and asphalt roads. There are also sidewalks of $69.8 \%$ gravel, $25 \%$ cobble stone and $5.2 \%$ is clay tiles surface materials. Since the terrain category of the area is flat and slightly ungulate water accumulates on the surface of unpaved roads and sidewalks which is resulting ponding on the surface of those roads and sidewalks are damaging them. Some drainage structure releases the water to farmlands of the farmers; some of them release water to residential while others release it to some other structures like roads. This drainage structures which releases water to other facilities are damaging the structures, and the surrounding farmers were block those structures which release water to their farms to protect their farm from damage.

In this study the terrain category of the town was classified by using ArcGIS software, based on standard and the slope of the terrain category of this town ranges between $0 \%$ to $6 \%$, which is flat and rolling terrain category. The terrain category affects the longitudinal slope of the drainage structure. At this terrain category the longitudinal slope of the drainage structure should be at least 2 percent. Unless this criterion does not achieve siltation can be resulted. This defect is 
highly observed in the Robe town.

During field observation accumulated silts or debris were observed with in the drainage structure. To identify causes of this silt accumulation the researcher was calculated the slopes of each drainage segment; and the slope ranges between 0.1 percent and 1.96 percent. But as stated above the longitudinal slope of the drainage structure must be greater than 2 percent, since the terrain category of the town is flat and rolling. Due to this the longitudinal slope of the existing drainage structure, can be a factor of siltation in this town. But this siltation is not only due to this flat slope but also, composition of waste in the drainage structure and blocked drainage structure, growing of plants in in the drainage structure is also other factors.

During the study, the capacity of existing drainage structure was also checked, and it was identified that the capacity of some existing drainage structure is less than the discharge value or required capacity while others were greater than the required capacity. Due to this both siltation and inadequate existing drainage capacity were identified as factor that causing street flood in the Bale Robe town.

To identify the major causes of this street floods the researcher was made a lot of investigation in addition to field observation and field survey. Some of these investigations were, the information about maintenance of existing drainage structure from town's municipality, availability of garbage can in the town, personnel or human power to participate in road clean and the town's administration bearing to maintain identified defects. Concerning these investigations, the researcher was identified there was no any maintenance that was made for existing drainage structures. The municipality employees some personnel to clean the road, but no one follow their activities. There is no garbage can or dust bin near the road and this is also identified during field observation. The municipality's has positive bearing to maintain identified defects based on the severity of defects and availability of finance.

Some defects of existing drainage structure that observed during the field observation and results in occurrence of street floods in the study area were clogged or blocked drain, deposited construction materials in and /or on existing drainage structure, flat slope, missed and /or damaged covers, litter in road reserve, solid material deposited in drainage structure and others.

\section{Recommendation}

Based on the finding of the research the following recommendations were provided:

Cover open drainage structures to improve safety of road users, to keep this drainage structure remain clean and also for aesthetic appearance.

Improve the longitudinal gradient of drainage structure by sealing to increase its slope based on availability of finance to reduce or improve sedimentation in drainage structure.

Remove sediments from drainage structure, early removing of vegetation that growth in drainage structure, properly cleaning of drainage structure before and after rain, early maintenance of drainage structure based on the severity of defects.

Improve the capacity of existing drainage structures that have a capacity of less than the required capacity by increasing their depth and /or width based on availability of finance and space.

\section{References}

[1] Pazwash, T, (2011). Urban Storm Water Management, Journal of the American Statistical Association,. Journal of Hydrology 89, 1175-1189.4.

[2] Sarireh, S. T. (2013). Causes of Cracks and Deterioration of Pavement on Highways in Jordan from Contractors' Perspective. Civil and Environmental Research, 16-27.

[3] Tiwari (2016). Themes in urban infrastructure in Ethiopia cities. Springer Briefs in Geography, DOI10, 107/978-3-37930403-8_2, 7-29.

[4] Getachew K. W and Tamene A. D, (2015). Assessment of the Effect of Urban Road Surface Drainage: A Case Study at Ginjo Guduru Kebele of Jimma Town. International Journal of Science, Technology and Society. 164-173.

[5] Amit, K. D. (2016). Drainage system in highways. Term paper in transportation engineering. Lovely professional University. Puniab-India, 1-47.

[6] Buren, R. Van, and J. T. Buma, (2012). Investigation of the Blue Spots in the Netherlands National Highway Network.

[7] Versini, P. -a., E. Gaume, and H. Andrieu, (2010a). Assessment of the Susceptibility of Roads to Flooding Based on Geographical Information: Test in a Flash Flood Prone Area (the Gard Region, France). Natural Hazards and Earth Systems Sciences 10: 793-803.

[8] Michael, R. A., N. Høegh, and F. Søren, (2010). "Development of a Screening Method to Assess Flood Risk on Danish National Roads and Highway Systems, 1-10.

[9] Bil, M., J. Sedonik, J. Kubecek, R. Vodak, and M. Bilova, (2014). Road Network Segments at Risk: Vulnerability Analysis and Natural Hazards Assessment. 1-18.

[10] Faísca, J. S., Baena, J., Baltzer, S., Gajewska, B., Nousiainen, A., Hermansson, Å, Erlingsson, S., Brenčič, M., and Dawson, A. (2012). Control of Pavement Water and Pollution Prevention Water in Road Structures. A. Dawson, ed., Water in Road Structures. Springer Netherlands, 299-356.

[11] Buchanan, B. P., Falbo, K., Schneider, R. L., Easton, Z. M., \& Walter, M. T. (2012). Hydrological impact of roadside ditches in an agricultural watershed in Central New York: implications for non-point source pollutant transport. Hydrological processes, 27 (17), 2422-2437.

[12] Magdi, M. E. Z. (2014). The Impacts of Poor Drainage on Road Performance in Khartoum. International Journal of Multidisciplinary and Scientific Emerging Research, 3 (1).

[13] ATB Väg (2014) a. Allmän teknisk beskrivning för vägkonstruktion. Kapitel $\mathrm{B}$ Inventering (in Swedish), Vägverket publikation, 2004 (111), 24-26. 
[14] Tacnet, J.-M., and E. Mermet, (2012). Analysis of Importance of Road Networks Exposed to Natural Hazards. Proceedings of the AGILE 2012 International Conference on Geographic Information Science 24-27.

[15] Douven, W. J. a. M, M. Goichot, and H. J. Verheij, (2013). "Best Practice Guidelines for the Integrated Planning and Design of Economically Sound and Environmentally Friendly Roads in the Mekong Floodplains of Cambodia and Viet Nam," synthesis report of the "Road and Floods" project. Mekong River Commision, Off. Secratariate Phnom Penh, 35143.

[16] Jones, J. A., F. J. Swanson, B. C. Wemple, and K. U. Snyder, (2010). Effects of Roads on Hydrology, Geomorphology, and Disturbance Patches in Stream Networks. Conservation Biology 14: 76-85.
[17] Mrango, H. E. (2012). Road Geometric Design Manual. Ministry of Works, Tanzania, 1-329.

[18] Ethiopia road authority (ERA), Robe town (2002). Robe Urban Infrastructure Asset Management plan. Robe, Ethiopia: federal democratic republic of Ethiopia Oromia regional state.

[19] Balasubramanian, A. (2 March 2017). Topography and Slope. Technical Report, 1-21.

[20] Stallings, S. L. (2010). Roadside ditch design and erosion control. Thesis submitted to the Faculty of Virginia Polytechnic Institute and State University in partial fulfillment of the requirements for the degree of Masters of Science in Civil Engineering, 1-170.

[21] Tonias, D. E. (2011). Highway Engineering. President HMC Group Ltd. Saratoga Springs. New York, 1-64. 